\author{
Mislav Benić1, Violeta Moretti² \\ ${ }^{1}$ Institut za hrvatski jezik i jezikoslovlje, Zagreb, ${ }^{2}$ Sveučilište Jurja Dobrile, Pula \\ mbenic@ihjj.hr, violeta.moretti@unipu.hr
}

\title{
On the aspect of the two present tense paradigms of the verb biti 'to be' in Croatian
}

\begin{abstract}
The article focuses on the issue of the aspect of the two present paradigms of the verb biti 'to be' in the Croatian language. Standard Croatian lexicography and grammars, such as Daničić (1880-1882: lemma bïti), Silić and Pranjković (2005: 88), explain the difference between the two present forms of this verb as one of verbal aspect (the present form jesam is considered imperfective, and budem perfective), while some grammars do not treat their aspect at all. The exceptions are Glasovi i oblici hrvatskoga književnog jezika (Babić et al. 1991: 688, 719), and the Serbo-Croatian grammar written in English by Brown and Alt (2004: 54), where budem is, accurately, described as a bi-aspectual form. Linguistic scholarship, however, addressed the aspect of budem several times (cf. Ivić 1955). Basing their conclusions on their exploration of the Croatian digital corpora - which had shown that budem can be used both in the contexts characteristic of perfective verbs and in some of those characteristic of imperfective verbs - the authors propose that the present form budem should be considered bi-aspectual. In accordance with this, they consider the traditional terms imperfective present and perfective present as inappropriate for these forms of biti and rather propose terms based on formal characteristics, whose accuracy cannot be questioned - the athematic present (jesam) and the thematic present (budem).
\end{abstract}

\section{Introduction 1}

The basic goal of this paper is to clarify the issue of aspect as well as the interrelationship between the two present paradigms of the verb biti 'to be' in the Stan-

1 We would like to thank David Mandić and Mladen Uhlik for technical support and proof-reading of the text and Jasmin Hodžić, Zenaida Karavdić and Željka Salopek for helping us acquire certain bibliographical units. We are also grateful to the peer-reviewers for their careful reading and useful advice. Special thanks to Wayles Browne for making us aware of Pavle Ivićs article (Ivić 1955) and especially for his useful comments. 
dard Croatian language (SC), having in view its common variations in actual usage. ${ }^{2}$ The authors will also provide a short résumé of historical approaches to the aspect of the present forms of the verb biti in SC. ${ }^{3}$ Verbal aspect is an important feature of the Croatian language, as well as of the verbal morphologies and semantics of other Slavic languages. According to Comrie, "aspects are different ways of viewing the internal temporal constituency of a situation" (Comrie 1976: 3), that is, while tense is concerned with the situation-external time, aspect is concerned "with the internal temporal constituency of the one situation" (Comrie 1976: 5). Although this is one of the widely adopted definitions, theoretical considerations on aspect often differ (cf. Dahl 1985: 69). The greatest issue is that of determining the exact boundary between aspect and actionality. It is not quite clear which denotations should be considered aspectual and which actional, whether aspect is just a grammatical category or not (cf. Dahl 1985: 26 f.). As this question is not necessarily relevant for the purpose of this paper, we only refer to syntactic criteria in order to determine the aspect. By the term 'aspect', however, we refer here to the opposition perfective vs. imperfective, mainly for practical reasons and in accordance with the Slavistic tradition. The semantic difference between the Slavic perfective and imperfective aspects, as it seems, cannot be established briefly and at the same time comprehensively, especially not if we take into account that the usage of the aspect is not completely identical in all Slavic languages. ${ }^{4}$ It can however be claimed that the two aspects, even in atypical cases, are quite easy to tell apart using syntactic criteria, which differ in various Slavic languages (see below). A verb can be perfective, imperfective or bi-aspectual.

The verb biti is generally bi-aspectual, but as it has two present paradigms - jesam and budem - it was considered to exhibit cleft bi-aspectuality (in the sense that one form of the verb is perfective while the other form is imperfective, in the same way as the aorist and imperfect tenses are normally associated with the perfective aspect and the imperfective aspect respectively). This does not correspond to the real situation, as will be shown in the article. For that reason, we are suggesting that the two sets of present forms of this verb should be referred to as athematic (jesam) and thematic (budem). The traditional Serbo-Croatian grammar and lexicography mostly explain the difference between athematic and thematic present forms

2 The linguistic material used in this work comes from the web pages in Croatian (mainly from the Croatian web corpus ( $\mathrm{hW}$ Wac) and Croatian National Corpus (HNK), acquired through Sketch Engine web tool search). Furthermore, our data from the urban idiom of Osijek and a corpus based on earlier research into the dialect of Kukljica on the island of Ugljan (Benić 2014; Benić (to appear)) provided additional examples of budem and jesam from an organic idiom and an urban dialect, spoken in two opposite peripheral parts of Croatia.

3 By 'historical', we mean the descriptions of the common Serbo-Croatian standard language, that underlies Croatian, Serbian, Bosnian and Montenegrin standard languages. We also use examples from contemporary Serbian and Bosnian as no relevant differences exist between them and the Croatian language, regarding the aspect of the present forms of biti.

4 For the complex problem of the meaning of the Slavic perfective and imperfective aspects and the difference in the usage of aspect in each group of Slavic languages cf. Dickey 2000. For the semantics of the two aspects in Slavic cf. also Zaliznjak and Šmelëv 2000: 34 sq.. 
of the verb biti as one of verbal aspect (Daničić (1863: 83), Budmani (1867: 101), Daničić (1880-1882: lemma bïti), Broz and Iveković (1901: lemma bïti), Leskien (1914: 462), Meillet and Vaillant (1924: 249), Maretić (1931: 242), Brabec, Hraste and Živković (1968: 127)). Less frequent are works that do not treat the aspect of the present forms of the verb biti at all, such as Gudkov (1969) and Stevanović (1986). The situation is similar in the contemporary grammars of BCMS languages. Most of them state that jesam is the imperfective present and budem the perfective present (Barić et al. (1997: 271), Kordić (1997: 38), Silić and Pranjković (2005: 88), Klajn (2005: 9.6.7.), Hammond (2005: 6.8.2.), Bičanić et al. (2013: 208)) and some grammars do not address this question at all (Jahić et al. (2004), Alexander (2006), Čirgić, Pranjković and Silić (2010) and Riđanović (2012)). The exceptions are Glasoviioblici hrvatskoga književnogjezika (Babićetal. 1991:688, 719), and the grammars of Wayles Browne (Browne 1993: 338) and Brown and Alt (2004: 54), where jesam is defined as imperfective and budem as both perfective and imperfective.

\section{Previous discussions on the aspect of the present forms of biti 'to be'}

The discussion on the aspect of the present forms of the verb biti is quite old and it should have been solved as in Brown and Alt (2004), but for some reason grammars follow Daničić and other scholars, whose considerations are mostly intuitive and not completely accurate. Jovan Vuković (1937) considered the form budem as imperfective, but his only 'proof' was his intuition. Đuro Grubor (1953: 321-325) mentioned the aspect of budem only briefly, defending the position of the traditional grammarians and lexicographers. He criticised Vuković for his misjudgement of the aspect of budem, claiming that it is not imperfective, but he admitted that, according to the contemporary speaker's intuition, it was not exclusively perfective either. In the year 1955, Pavle Ivić published the key article on this topic, titled 'O vidu glagolskog oblika budem' [On the aspect of the verb form budem]. According to Ivić, the present form jesam is clearly imperfective, but the form budem cannot be considered perfective only (as, for example, the present ostanem 'I stay, I remain' is) as was stated by Grubor and by the traditional grammar, but neither imperfective only, as Vuković thought.

Ivić noticed and accurately defined a number of points (which will be listed further on in the text) concerning the aspect of the present forms of biti. Although we generally agree with him, there are certain points that ought to be discussed in greater detail. First of all, while Ivić criticizes Vukovićs argumentation as based on intuition, his own propositions are not flawless either. Instead of defining the contexts in which the present budem functions as a perfective or an imperfective verb respectively, Ivić gave mere examples which he assumed to prove the imperfectiveness and the perfectiveness of budem, corroborating them with few arguments. Secondly, almost all of his examples and arguments can be challenged as they are merely clues and not actual proofs. Thus, the only example Ivić provided 
that unquestionably verifies the imperfectiveness of the present budem is Prestaoje da bude interesantan. (Ivić 1955: 238) 'He stopped being interesting', but Ivić does not isolate it from the rest of the material and gives no clarification of how it proves the imperfectiveness of the present form budem. Likewise, Ivić does not bring any incontestable evidence for the perfectiveness of this form.

Further writings on this topic are Vuković (1957), Grickat (1958: 67-68) and Veljković (2015), who do not represent significant advances in the understanding of the aspect of budem in comparison to Ivić. The hindmost paper (Veljković 2015) is particular in that it tries to determine the aspect of the auxiliary verb biti. We believe that the discussion on the aspect of the auxiliary verb biti (at least from a purely synchronic point of view) does not make sense, so we do not attempt to determine the aspect of the presents of the verb biti in analytic verbal forms. Although we also treat the form budem in its function of an auxiliary verb at the end of our article, we are interested only in the distribution of the passive that is formed with it, and not in the aspect of the auxiliary verb.

\subsection{Ivić's considerations}

While critically examining Grubor's argumentation, Ivić made an effort to bring more clarity into question of the aspect of the present forms of biti. In this section, we will briefly represent Ivićs argumentation and draw attention to its weaknesses.

\subsubsection{Clues pointing to the imperfectiveness}

Ivić’s first example (Ivić 1955: 238)

\begin{tabular}{|l|l|}
\hline (1) & $\begin{array}{l}\text { Želim da dete koje će ti se roditi bude 'be-3SG.PRS2" celog svog veka zdravoi } \\
\text { snažno. }\end{array}$ \\
\hline & 'I want that the child that will be born to you be healthy and strong all its life.' \\
\hline
\end{tabular}

was intended to be the proof of the imperfectiveness of the verbal form budem, but in fact bude can be substituted here by the perfective verb ostane 'stay/remain3SG.PRS', i.e. this particular context does not indicate undoubtedly the imperfectiveness of budem. The verb ostati 'to stay' is undoubtedly perfective, although it is atypical as it can be accompanied by expressions of duration that usually occur with imperfective verbs, such as the accusative or, more rarely, genitive of duration of time (ostati cijelu godinu/cijele godine), as well as with the instrumental of time (ostati satima, danima, godinama). The perfectiveness of budem could be atypical in

5 We mark (je)sam as PRS1 and budem as PRS2. The same goes for the verbs imati, moći and htjeti: the presents imam, mogu and (ho)ću are marked with PRS1, while the presents imadnem, mognem and htjednem are marked as PRS2. Emphatic and non-emphatic forms such as sam and jesam, or ću and hoću are not discriminated in the glossing notation as we do not consider the difference between them relevant for this paper. Presents such as mogadnem, imadem do not occur in this paper. 
the same way. In any case, there is no reason for rejection of such a possibility in advance.

Secondly, the author stated that the infinitive biti 'to be', chiefly considered imperfective by Grubor, can typically be supplanted by the construction $d a+b u d e m$, which corresponds to it in meaning, and, according to Ivić, in aspect, as in

\begin{tabular}{|l|l|}
\hline$(2 \mathrm{a})$ & Nemoj biti be-INF' lud. \\
\hline & 'Do not be crazy.' \\
\hline
\end{tabular}

which can be transformed into nemoj da budešlud (Ivić 1955: 238). But he never expanded on his assertion. Besides that, a perfective verb can occur in this type of contexts, as in (2b)

\begin{tabular}{|l|l|l|l|}
\hline (2b) & Nemoj raditi. 'work/do-INF-IPFV' / & Nemoj uraditi. 'do-INF-PFV' \\
\hline & 'Do not work.' & $/$ & 'Do not do (have it done).' \\
\hline
\end{tabular}

As the next clue, further in his argumentation, Ivić asserted that

\begin{tabular}{|l|l|}
\hline (3a) & Nemoj da budeš. 'be-2SG.PRs2' \\
\hline & 'Do not be.' \\
\hline
\end{tabular}

can be substituted by the negative imperative ne budi 'do not be', which can only be formed with imperfective verbs (Ivić 1955: 238-9). Stating that the (simple) negative imperative is formed only of imperfective verbs, Ivić neglects the fact that the negated imperative is almost always formed with imperfective verbs, but not exclusively. The most well-known exception is

\begin{tabular}{|l|l|}
\hline (3b) & Ne zaboravi(te). 'forget-2SG(2PL).IMP-PFV' \\
\hline & 'Do not forget.' \\
\hline
\end{tabular}

We must not omit the often cited Ten Commandments, where negated imperatives such as

\begin{tabular}{|l|l|}
\hline (3c) & Ne ukradi. 'steal-2SG.IMP-PFV' \\
\hline & 'Thou shalt not steal.' \\
\hline
\end{tabular}

or

\begin{tabular}{|l|l|}
\hline (3d) & Ne sagriješi 'sin-2SG.IMP-PFV' bludno. \\
\hline & 'Thou shalt not commit adultery.' \\
\hline
\end{tabular}

are a norm. Another Ivić's oversight is, however, much more important. The simple imperative ne budi in his example is probably really imperfective, but this 
does not necessarily prove the imperfectiveness of the present in the periphrastic negative imperative nemoj da budeš. Namely, the perfective aspect is indeed marginal in a simple imperative, but it is quite common in a periphrastic imperative with nemoj, with the imperfective simple imperative sometimes covering the denotation of a periphrastic imperative of both aspects in certain cases. This way the sentence ne čini to aproximately corresponds to the sentences nemoj to činiti and nemoj to učiniti. In accordance with that, the tacit exclusion of the possibility that a perfective verb in the periphrastic imperative nemoj da budeš corresponds to an imperfective verb in simple imperative ne budi is inadmissible, no matter how counterintuitive this possibility might seem. ${ }^{6}$

Ivićs next point is that the future II form budem bio can always be substituted by budem as in

\begin{tabular}{|l|l|}
\hline (4) & Ako budeš (bio) dobar cele iduće školske godine... \\
\hline & 'If you are good throughout the next school year...' \\
\hline
\end{tabular}

He added that it was impossible to challenge the idea that the aspect of the verbal adjective bio can be imperfective (and it is imperfective very often) and that it is a well-known fact that the aspect of a future II form depends on the aspect of the verbal adjective (Ivić 1955: 239). This statement, again, cannot be taken as evidence for the imperfectiveness of the present form budem, as it lacks further argumentation, and furthermore, budeš can be supplanted by the perfective verb ostaneš 'remain-2SG.PRS' in the above example.

The next clue by Ivić, concerning the imperfectiveness of budem, deals with its usage in volitive sentences, where a subordinate clause can contain both perfective and imperfective verbs. According to Ivić, verbs denoting volition, intention etc., such as nameravam 'I intend', are complemented by budem and never by jesam, which means that budem also occurs in contexts that belong to imperfective verbs (Ivić 1955: 239). This however is not quite true, as we will show later, as verbs of volition (verba voluntatis) can govern both the present form budem and (je)sam in a subordinate clause. Secondly, it could be claimed that budem is only perfective in this type of clauses because it could denote posterior situations, i.e. a sort of inchoative actionality. If it does not denote inchoative actionality, it could refer to the same Aktionsart as the perfective verb ostati 'to remain'. Finally, there are cases in which aspect neutralization occurs, as are for example the present tense forms denoting planned future predication, cf. sutraću otići 'go-INF.PFV' u Zagreb 'I am going to go to Zagreb tomorrow' > sutra odlazim 'go-1SG.PRS.IPFV' u Zagreb 'I am going to Zagreb tomorrow', and not ** sutra odem 'go-1SG.PRS.PFV' u Zagreb. If we did not know the aspect of the present odlazim, we might conclude that it is actually per-

6 One of the classic papers on the aspect of the negated imperative in Slavonic languages is the one written by Milka Ivić (Ivić 1958). A review of other relevant bibliography and some diachronic data are given in Šimić and Vela 2018. 
fective, on the basis of the future form otici ću. Why would we then not assume the same aspect neutralization in the case of the present budem in volitive sentences, whereby both aspects are neutralized into the perfective aspect?

The next clue that Ivić adduced as the proof of the imperfectiveness of budem is the new perfectivisation of the type uzbudem (Ivić 1955: 239; citing Grubor 1953) which occurs when speakers do not quite feel the form budem as perfective. The question is, however, whether we can claim that the presents htjednem 'want-1sG. PRS2' and mognem 'can-1SG.PRS2' are not perceived by speakers as sufficiently perfective, and whether this is the real reason for the emergence of the new present forms ushtjednem and uzmognem, or there might be another reason to that.

\subsubsection{Clues pointing to the perfectiveness}

Ivić's argumentation in the case of the perfectiveness of the present form budem is almost completely based on paraphrasing, which can hardly be considered a reliable indicator of any grammatical characteristic at all. His examples (Ivić 1955: 240) include

\begin{tabular}{|l|l|}
\hline (5a) & $\begin{array}{l}\text { Svisu zahtevali da početak bala bude 'be-3SG.PRS2' ranije nego što je on } \\
\text { predložio. }\end{array}$ \\
\hline & 'Everyone has required that the ball begin earlier than he suggested.' \\
\hline
\end{tabular}

(5b) Izvršenje smrtne kazne treba da bude 'be-3SG.PRS2' sutra u šest sati. 'The execution of the death penalty should be tomorrow at 6 o'clock.'

According to Ivić, bude can be replaced in both cases with the perfective verb dogodi se, but not with the imperfective događa se (both meaning 'to happen'). The same goes for his next example (Ivić 1955: 240)

(6) To što ti hoćeš neće moći da bude 'be-3SG.PRS2'.

'What you want will not be possible.'

where da bude can be paraphrased as the perfective da se dogodi/ostvari/izvrši, and not as the imperfective da se događa/ostvaruje/izvršuje (both translatable as 'happen/complete/be done'). Ivić's examples, however, give no exact proof of perfectiveness because, if we follow his methodology, the imperfectiveness of budem in these examples might also be proven, in theory, by the replacement of bude with ima mjesto 'takes place' (currently non-existent in Croatian though).

Further on, Ivić stated that in (7) the verb bude is used in a context that only allows the perfective present (Ivić 1955: 240), ignoring the fact that both imperfective and perfective verbs in the historical present can stand next to each other, as for example in (8) 
(7) Aon ne bude 'be-3SG.PRS2' lenj, već sedne na voz i otputuje da raspravistvar. 'And he was not lazy, but he took a train and travelled away to discuss the matter.'

(8) Alion se ne brine 'worry-3SG.PRS' za sebe, većse baciu rijeku da pomogne 'help-3SG.PRS' djetetu.

'But he does not mind himself and jumps into the river to help the child.'

Yet bude in (7) sounds more natural than se ne brine 'does not care/worry' in (8) and it is presumably perfective indeed.

The next clue in Ivić's argumentation are examples in which he points to the contexts in which the future II, as well as the perfective present correspondent to the future II, are used (Ivić 1955: 240).

(9) Devojkaće bitionoga kobude 'be-3SG.PRS2' prvinacilju.

'The girl will be given to the one who first arrives at the finish line.'

(10) Čim budeš 'be-2SG.PRS2’ u Beogradu, poseti Mirka i predaj mu moje pismo. 'As soon as you are in Belgrade, visit Mirko and give him my letter.'

In his understanding, budem can be replaced with the perfective present exclusively (Ivić 1955: 240), as in

\begin{tabular}{|l|l|}
\hline (11a) & $\begin{array}{l}\text { ko se } \text { nade 'find-3SG.PRS-PFV' prvi na cilju / stigne 'arrive-3SG.PRS-PFV' } \\
\text { prvi na cilj, }\end{array}$ \\
\hline & 'who happens to be the first at the finish line/ first arrives at the finish line' \\
\hline
\end{tabular}

and

\begin{tabular}{|l|l|}
\hline (11b) & $\begin{array}{l}\text { čim stigneš 'arrive-2SG.PRS-PFV' u Beograd / čim se nadeš 'find-2SG.PRS- } \\
\text { PFV' u Beogradu. }\end{array}$ \\
\hline & 'as soon as you arrive in Belgrade / as soon as you happen to be in Belgrade' \\
\hline
\end{tabular}

The typical imperfective present cannot really function in such contexts because as near as only the perfective present can correspond to the future II. In this type of contexts, however, the imperfective future II can occur.

\begin{tabular}{|l|l|}
\hline (11c) & $\begin{array}{l}\text { Čim se budeš nalazio 'find-2SG.FUT II-IPFV' u Beogradu, posjeti 'visit-2SG. } \\
\text { PRS-IPFV' Mirka. }\end{array}$ \\
\hline & 'As soon as you find yourself in Belgrade, visit Mirko.' \\
\hline
\end{tabular}


Despite that, the imperfective future II in (11c) is not a frequent and particularly common variety, but it is possible in this sentence, and it is completely common or even obligatory in some examples. Cf. the pairs:

\begin{tabular}{|l|l|}
\hline (11d) & $\begin{array}{l}\text { Čim saznaš 'find out, know-2SG.PRS-PFV' / čim budeš znao 'know-2SG. } \\
\text { FUT II-IPFV' nešto konkretno, javi mi. }\end{array}$ \\
\hline & 'As soon as you know anything concrete, let me know.' \\
\hline
\end{tabular}

(11e) Čim se oporaviš 'recover-2SG.PRS-PFV'/čim se budeš bolje osjećao 'feel-2SG. FUT II-IPFV', posjeti Mirka.

'As soon as you get better / start feeling better, visit Mirko.'

It is quite certain that the verbs znati 'to know' and osjećati se 'to feel' in (11d) and (11e) are imperfective. In the same way the present budem in (9) and (10) can be imperfective too. ${ }^{7}$ In fact, Ivić himself stated previously (Ivić 1955: 239) that every future II form of the verb biti can be replaced with the simple budem, whereas the simple budem can be imperfective, but he had obviously failed to notice it while listing the examples (9) and (10) as the objective proof of the perfectiveness of the present budem (Ivić 1955: 241). Replacing budem bio with budem is presumably not related (only) to the aspect of the present budem, but is probably conditioned by the avoidance of repetition. The analogous situation can be found in a number of dialects ${ }^{8}$ in which the perfect and pluperfect of the verb biti do not differ, i.e. there is only one form, which corresponds to the perfect, and secondly, the conditional I and the conditional II of the verb biti do not differ (there is only one form, which corresponds to the conditional I).

Ivić's next clue concerns the usages in the Croatian Kajkavian dialect and in the region of Banat (the village of Kruščica), where the equivalents of the present budem are used as future I, that is, the perfective present in used to denote future (Ivić 1955: 241). This clue can be disregarded on the same basis as the previous one.

7 The interrelationship of the perfective and the imperfective aspect in temporal čim clauses is interesting enough, but further discussion would take too much space. It is however worth mentioning that the imperfective future II fits into this type of clauses easier than other tenses. Cf.

\begin{tabular}{|l|l|}
\hline (11f) & Čim strojevi budu radili 'work-3PL.FUT II-IPFV' (=budu 'be-3PL.PRS2' ispravni), moći ćemo isporučivati robu. \\
\hline & 'As soon as the machines start working (are in good condition), we will be able to deliver the goods.' \\
\hline (11g) & Čim su strojevi bili ‘be-3PL.PRF' ispravni (?su radili 'work-3PL.PRF-IPFV'), mogli smo isporučivati robu. \\
\hline & 'As soon as the machines were in good condition (?were working), we were able to deliver the goods.' \\
\hline
\end{tabular}

In our opinion, this does not imply that each future II is perfective in this type of clauses, as might be assumed. In both (11d) and (11e) the perfect tense of imperfective verbs is possible. Besides that, future II (budu radili) in (11f) can be replaced with the present of the perfective verb proraditi 'start to work'. The imperfective future II can be more easily understood as inchoative as it is a future tense. 
Concerning the presents budnem/bidnem 'be-1SG.PRS' in vernacular idioms, Ivić correctly stated that the suffix $-n$ - occurs in the present stem of the Type 1 perfective verbs, such as rečem : reknem 'I say' and ležem : legnem 'I lie down' (Ivić 1955: 241-2), with a number of exceptions. While admitting that there are exceptions, Ivić overlooked that budem could also be an exception of the same kind (such as, for example, znadnem, imadnem, $\operatorname{mog}($ ad)nem).

Further on, Ivić argued that budem, the same as (other) perfective verbs in the present, cannot denote non-repeating situations in declarative clauses accompanying verbs of saying and thinking, nor can it denote the true present in independent clauses (Ivić 1955: 242). That is true, but it cannot prove the perfectiveness because budem is not used in these cases and it is pointless to claim that budem is perfective in the cases in which it cannot occur.

Despite the failure to provide a precise picture, Ivić was on the right trail, and more than that. His article is in accordance with the linguistic methods of the time and space it belonged to. Ivićs colleagues who wrote about verbal aspect equal him in the scarce usage of syntactic criteria, which are more precise than language intuition and paraphrasing. Moreover, the weak impact of Ivićs article on the further understanding of the aspect of the present forms of the verb biti was not due to its meagre argumentation but, unfortunately, very likely did not develop because at that time the thirty-year-old Ivić was not able to challenge the linguistic authority of Daničić, Maretić and other scholars of that period. Later on, his article was mainly forgotten.

\section{The aspect of the present form budem - discussion}

We will pick up where Ivić left off and point at the contexts that indicate the aspect of the present forms of the verb biti. While the athematic present form (je) sam is clearly imperfective and it needs no further argumentation, the aspect of the thematic present form budem is questionable and needs further discussion.

\subsection{Contexts that point to the perfectiveness of budem}

The following contexts, i.e. usages, point to the perfectiveness of the thematic present of the verb biti 'to be'.

\subsubsection{Actual (true) present}

The present budem is not used as the actual (true) present in independent clauses (in which it agrees with perfective verbs), cf. 


\begin{tabular}{|l|l|l|l|}
\hline (12) & $\begin{array}{l}\text { Gdje se trenutno } \\
\text { nalaziš? }\end{array}$ & $\begin{array}{l}\text {-Uškoli sam. 'be-1SG. } \\
\text { PRS1' }\end{array}$ & $\begin{array}{l}/^{* *} \text { Budem ** 'be-1SG.PRS2' } \\
\text { uškoli. }\end{array}$ \\
\hline & $\begin{array}{l}\text { 'Where are you cur- } \\
\text { rently?' }\end{array}$ & - 'I am at school.' & $/^{* *}$ 'I be at school.' \\
\hline
\end{tabular}

This context literally only points to the perfectiveness but it does not prove it. The fact that a verb is not used in one of the contexts typical of imperfective verbs does not necessarily mean that it is used in contexts typical of perfective verbs. Here we deal with a context in which the present budem cannot appear, but in certain other contexts budem functions as an imperfective verb. For that reason, the present budem cannot be considered a typical bi-aspectual verb (i.e. one used in any context typical of perfective and imperfective verbs). In this case, we deal with a special type of bi-aspectuality where the verb is not used in certain contexts typical of one of the aspects.

\subsubsection{Da clauses depending on pričekati 'to wait (until X occurs)'}

Only perfective verbs can occur in da clauses complementing the verb pričekati 'to wait (until X occurs)', in which the predicate of the dependent clause refers to a change for which the subject of the dependent clause needs to wait to occur. These are such sentences as

\begin{tabular}{|l|l|}
\hline (13) & Pričekaj da dođe 'come-3SG.PRS.PFV' vlak. \\
\hline & 'Wait for the train to come.' \\
\hline
\end{tabular}

In this type of da clauses, the present budem is common, but jesam never occurs. Cf.

\begin{tabular}{|l|l|}
\hline (14) & Pričekaj dajelo bude 'be-3SG.PRS2' gotovo. \\
\hline & 'Wait until the food is finished.' \\
\hline
\end{tabular}

\begin{tabular}{|l|l|}
\hline$(15)^{9}$ & Pričekaj da on bude 'be-3SG.PRS2' u stanu, pa ga probaj nazvati. \\
\hline & 'Wait until he is in the apartment, and then try to call him.' \\
\hline
\end{tabular}

This rule does not concern the marginally acceptable sentences, such as (16), where the predicate does not denote an expected change.

\begin{tabular}{|l|l|}
\hline (16) & Pričekaj da se on malo igra 'play-3SG.PRS.IPFV', pa će ti vratiti. \\
\hline & 'Wait until he has played for a while, and then he will return it [=a toy] to you.' \\
\hline
\end{tabular}

9 In (15) a verb of motion could be slightly more suitable than budem. 


\subsubsection{Clauses governed by predicates denoting fear}

In SC, in volitive type clauses the present is always or almost always perfective when governed by predicates denoting fear. ${ }^{10}$ In this type of clauses, the imperfective present can be found only rarely, as its usage in these contexts can lead to an unwanted homonymy. ${ }^{11}$ On the other hand, in declarative clauses governed by predicates expressing fear, the imperfective present is fairly common. In volitive type clauses, the present budem governed by predicates expressing fear occurs regularly, while it is not common in declarative clauses with predicates denoting fear. This is evident from examples (17), (18), (19) and (20).

a) The present of the verb biti in subordinate volitive type clauses governed by verbs denoting fear:

\begin{tabular}{|l|l|}
\hline$(17)$ & Bojim se da ne bude 'be-3SG.PRS2' gore. \\
\hline & 'I am afraid it might get worse.' \\
\hline
\end{tabular}

(18)

Bojim se da ti hlače ne budu 'be-3PL.PRS2' (pre)tijesne.

'I am afraid the trousers might be (too) tight for you.'

\begin{tabular}{|l|l|}
\hline (19) & Bojim se da on, kad ga mi budemo tražili, ne bude 'be-3SG.PRS2' negdje drugdje. \\
\hline & 'I am afraid that, when we are looking for him, he might be somewhere else.' \\
\hline
\end{tabular}

b) The present of the verb biti in subordinate clauses in declarative sentences governed by verbs denoting fear

(20) Bojim se da takvo ponašanje nikad nije 'NEG-be-3SG.PRS1' korisno.

'I am afraid that this sort of behaviour is never useful.'

Cf. also:

(20b) (?)Bojim se da takvo ponašanje nikad ne bude 'be-3SG.PRS2' korisno.

10 This refers to sentences such as Bojim se da ne napraviš neku glupost. 'I'm afraid you'll do something stupid', in which the subordinate clause can refer only to a posterior situation. In the Croatian language, there is always a negation in this type of subordinate clauses. They denote that the subject of the main clause is guessing that an undesired situation might take place. This type of clauses differs from declarative clauses governed by predicatives of fear, such as Bojim se da ne radiš kako treba. 'I'm afraid you're not doing it the right way', which can refer to anterior, simultaneous and posterior situations and can be both affirmative and negative. When they are negative, they denote that the subject of the main clause speculates upon the absence of a desired situation (rather than upon the occurrence of an undesired situation, as in the case of volitive type clauses). Volitive type and declarative clauses with verbs denoting fear also differ in this respect: when governing declarative clauses, verbs denoting fear display a meaning close to that of verbs of saying much more often than they do when governing volitive type clauses. For more details on the term volitive type clauses see under 4 .

11 Such homonymy occurs in cases where a declarative clause is governed by the verbs denoting fear (with a subordinate clause containing a negated imperfective present form). 
The perfectiveness of the present budem is thus relatively undoubtedly proved by the contexts in 3.1.2 and 3.1.3, whereas the context in 3.1.1 is not more than just a clue.

\subsection{Contexts pointing to the imperfectiveness of the present budem}

The following contexts, i.e. usages, point to the imperfectiveness of the thematic present of the verb biti.

\subsubsection{Phasal verbs and expressions that denote development of a process}

Phasal verbs are those that denote phase (the beginning, continuation or end) of a certain situation, i.e. verbs such as početi 'to begin', nastaviti 'to continue', prestati 'to stop'. In SC, only imperfective verbs can be governed by these verbs. This rule concerning phasal verbs applies to almost all Slavic languages and dialects, with a few exceptions, such as in verbs denoting finishing actions in certain dialects of Istria in Croatia ${ }^{12}$, as well as in Upper Sorbian, where perfective verbs are also permitted with phasal verbs ${ }^{13}$, or perhaps in Czech, where phasal verbs can govern verbs zúčastnit se 'to participate' and soustředit se 'to concentrate', which are traditionally considered perfective ${ }^{14}$. In SC, there appear to be no exceptions. Phasal verbs are usually complemented by the infinitive and since the verb biti has only one infinitive form these examples do not reveal much regarding its aspect. In colloquial language, 15 however, a number of cases are noted where the infinitive is replaced by $d a+$ present $^{16}$, in which bude fits better than $j e(s t)^{17}$, as exemplified by (21), (22), (23) and (24).

\begin{tabular}{|l|l|}
\hline$(21)$ & $(. .$.$) znači da jednom nije bio paje počeo da bude (...) 'be-3SG.PRS2'.$ \\
\hline & $\begin{array}{l}\text { '(...) it means there was a time when He [i.e. God] was not and then He be- } \\
\text { gan to be (...)' (forum.hr) }\end{array}$ \\
\hline
\end{tabular}

12 Verbs such as finit/finievät (and similar, depending on the dialect) 'to finish' govern perfective verbs, cf. Orbanići (Kalsbeek 1998: 286): Sät finjiêvan učisstit 'clean-INF-PFV'solâto. 'Now I am finishing cleaning the lettuce'; Kömoć san finila skopät 'dig-INF-PFV' do nöći. 'I hardly [managed to] finish digging [the piece of land] before dark'; cf. Mlini (the Buzet dialect): Kad su finile žénske požét 'harvest-INF-PFV'... 'When the women had finished harvesting...' (example obtained by courtesy of David Mandić).

13 Cf. Faske 1981: 181.

14 Cf. Veselý 2011.

15 Examples acquired by a Sketch Engine search in Croatian media web pages.

16 Most of our examples involving $d a+$ present constructions can be attributed to non-Croatian Central South Slavic idioms, but we have noticed many cases where Croatian speakers use the same construction, as for example in the Pula urban dialect, where this construction spread from a numerous Serbian linguistic community during the second half of the $20^{\text {th }}$ century. Secondly, there are parts of continental Croatia for which we must assume that they share this feature with certain Serbian dialects (as they all represent a dialectal continuum). However, as there is no difference regarding aspect between the usage of the infinitive and a clause with a finite verb when governed by phasal verbs, we take them into account for our argumentation.

17 The athematic present (je)sam, although imperfective, does not occur with phasal verbs because of its stative nature (cf. Padučeva 2010: 147; cf. also the incompatibility of the bi-aspectual stative verb isplatiti se 'to be worthwhile' with phasal verbs). 
(22) Kada se puno ljudi interesuje ... isto počne da bude 'be-3SG.PRS2' interesantno zamedije.

'When many people are interested, the same thing becomes interesting to the media.' (advance.hr)

(23) (...) bio bi tek obična sebična baraba koja ustaje i odlazi kad god prestane da bude 'be-3SG.PRS2' zabavno.

'(...) [he] would be just a selfish punk who gets up and leaves whenever it stops being interesting.' (booksa.hr)

(24) Upravoje zato narodna muzika prestala da bude 'be-3SG.PRS2' veliki tabu u Hrvatskoj (...)

'It is exactly for this reason that folk music stopped being a big taboo in Croatia.' (tjedno.hr)

Somewhat similar to phasal verbs are expressions such as odsad pa nadalje 'from now on', ubuduce 'henceforward' and i dalje 'still'. When these expressions are referring to a non-repeating situation, the situation is almost always expressed by an imperfective verb. With this type of expressions in SC the present budem is again more common, as in

\begin{tabular}{|l|l|}
\hline (25) & Želim da ti i dalje bude 'be-3SG.PRS2' dobro. \\
\hline & 'I wish you go on being well.' \\
\hline
\end{tabular}

Yet these expressions are not a completely reliable indicator of imperfectiveness, cf. (26), where the perfective verb ostaneš 'you remain' is semantically very close to the phrase i dalje boraviš 'you are still residing'.

\begin{tabular}{|l|l|}
\hline (26) & Želim da i dalje ostaneš 'stay-2SG.PRS.PFV' na selu \\
\hline & 'I want you to remain in the country.' \\
\hline
\end{tabular}

Really reliable indicators of imperfectiveness, however, besides those in the clauses governed by phasal verbs, are expressions denoting the development of a situation. When referring to a non-repeating situation, these expressions only accompany imperfective verbs. Such expressions are iz sata u sat 'hour after hour', iz dana u dan 'day by day' etc., as well as the adverbial and adjectival comparative constructions with the particle sve, such as sve bolje (i bolje), sve ljepše (i ljepše), sve brže ( $i$ brže) (corresponding to English expressions such as better and better, more and more beautiful, faster and faster) indicating gradual increase. With this type of expressions, both presents of the verb biti can occur, as in (27a) and (27b). 


\begin{tabular}{|l|l|}
\hline (27a) & Iz dana u dan mije 'be-3SG.PRS1' bolje. \\
\hline & 'I am getting better day by day.' \\
\hline
\end{tabular}

\begin{tabular}{|l|l|}
\hline (27b) & Želim da ti iz dana u dan bude 'be-3SG.PRS2' bolje. \\
\hline & 'I wish you got better with every new day.' \\
\hline
\end{tabular}

Although these are relatively reliable indicators, the border between non-repeating and repeated situation is by no means sharp, and in the case of repeated situations, the verb could theoretically be perfective. ${ }^{18}$

Further examples are:

\begin{tabular}{|l|l|}
\hline$(28)$ & (...) svakodnevni rad će nam dati impuls da to bude 'be-3SG.PRS2' sve bolje i bolje. \\
\hline & 'Everyday work will motivate us to make it ever better.' (mok.hr) \\
\hline
\end{tabular}

(29) Umjesto da budu 'be-3PL.PRs2' sve bolje, one su sve slabije kako se bližimoljetnom zatišju.

'As we approach the summer standstill, they are increasingly weaker, instead of becoming ever better.' (liderpress.hr)

(30) Želimo da vas bude 'be-3SG.PRS2' sve više i više na listama.

'We wish to see you in ever greater numbers in the lists.' (squashtower.hr)

(31) Oni omogućuju kosi da iz dana u dan bude ‘be-3SG.PRS2’ snažnija ijača iznutra

'They enable the hair to get more vigorous and stronger by the day.' (garden.hr)

\subsubsection{Indicators of an included time}

Only an imperfective verb can denote a process extending over a short interval of time and encompassing it, i.e. including it (cf. Padučeva 2015: 177; Maslov 2004: 99 sq.). The time interval of the main clause in the following examples thus can be encompassed by the dependent clause time interval, that is it can be included by it, but only if the dependent clause contains an imperfective verb.

18 There are also examples in the corpus, in which verbs are definitely perfective, such as:

\begin{tabular}{|c|c|}
\hline$(27 \mathrm{c})$ & $\begin{array}{l}\text {... koji se brinu da naš grad iz dana u dan postane 'become-3SG.PRS' 'i ostane 'stay-3SG.PRS 1' sve ljepši. } \\
\text { (dzo-rijeka.hr) }\end{array}$ \\
\hline & '... who care that with every new day, our city becomes and stays more and more beautiful.' \\
\hline \multicolumn{2}{|l|}{ or } \\
\hline \multirow[t]{2}{*}{$(27 d)$} & Ipak, ni to ga nije spriječilo da iz dana u dan postane 'become-3SG.PRS1' sve bolji.(dnevno.hr) \\
\hline & 'Yet, not even that stopped him from becoming better and better day by day.' \\
\hline
\end{tabular}

but these are not considered acceptable sentences by all Croatian speakers. 


\begin{tabular}{|l|l|}
\hline$(32)$ & Došao sam kad si kuhala 'cook-2SG.PST-IPFV'ručak. \\
\hline & 'I came while you were cooking lunch.' \\
\hline
\end{tabular}

\begin{tabular}{|l|l|}
\hline (33) & Došao sam kad si skuhala 'cook-2SG.PST-PFV' ručak. \\
\hline & 'I came when you had cooked lunch.' \\
\hline
\end{tabular}

Both examples contain a well-formed Croatian sentence, but only in the first one, the interval of the main clause is encompassed by, i.e. included in, the interval of the dependent clause. As for the present budem, it can easily encompass shorter intervals.

(34) Doćiću kadbudeš 'be-2SG.PRS2’kodkuće.

'I will come when you are at home.'

(35) Pobrinuo sam se da netko bude 'be-3SG.PRS2'u kući kad dođe majstor.

'I have made sure that somebody is at home when the repairman arrives.'

\subsubsection{Non-repeating unfinished situations in clauses introduced by dok 'while' paralleled by the situation of the main clause}

Only or almost only imperfective verbs can occur in temporal dok clauses expressing non-repeating unfinished situations, paralleled with an unfinished or finished situation in the main clause, and in which the negation of the verb has its typical function ${ }^{19}$ (cf. (36)-(39)). In such sentences, besides the future I in the main clause, the present budem usually occurs in the dependent clause, rather than the future II budem bio. That is to say, in such sentences, the present budem functions as the imperfective future II, but it cannot function as the imperfective present.

\begin{tabular}{|l|l|}
\hline (36) & (...) onda ću se smijati, dok mi u jednoj rucibude ‘be-3SG.PRS2’ Heineken (...). \\
\hline & '(...) then I'll be laughing, with a Heineken in one hand (...)’ (viatrade.hr) \\
\hline
\end{tabular}

\begin{tabular}{|l|l|}
\hline (37) & Dokbudem 'be-1SG.PRS2' (bio) 'be-PTCP.ACT.3SG.M' u kuhinji, pazit ću najelo. \\
\hline & 'While I am in the kitchen, I will be taking care of the meal.'
\end{tabular}

\begin{tabular}{|l|l|}
\hline (38) & $\begin{array}{l}\text { Dokne budem 'be-1SG.PRS2' (bio) 'be-PTCP.ACT.3SG.M' u kuhinji, } \\
\text { neću paziti najelo. }\end{array}$ \\
\hline & 'While I am not in the kitchen, I will not be taking care of the meal.' \\
\hline
\end{tabular}

19 By 'typical' we refer to a verb without the negation denoting a certain situation and a verb with the negation expressing the absence of the situation. 
(39) Dokbudem 'be-1SG.PRS2’ (bio) ‘be-PTCP.AKT.3SG.M’ izvan kuhinje, neću paziti najelo.

'While I am out of the kitchen, I will not be taking care of the meal.'

Perfective verbs (even the atypical ones) in such sentences function differently, as shown by (40), (41) and (42).

(40) Voda će ključati dokostane 'stay-3SG.PRS-PFV' na štednjaku. 'The water will be boiling as long as it stays on the stove.'

(41) Voda neće ključati dokne ostane ‘stay-3SG.PRS.PFV’ na štednjaku. 'The water will not boil until it is on the stove.'

(42) Voda neće ključati dok ostane ‘stay-3SG.PRS.PFV' dalje od štednjaka.(?)

'The water will not boil as long as it stays away from the stove.'

While the meaning of the present budem in (37)-(39) can be interpreted in the same way, the meaning of the atypical perfective verb ostati in (41) differs from the meaning in (40) and (42), i.e. in (40) and (42) the verb ostati means 'continues staying' while in (41) it means 'stays for a while'.

The cases of typical perfective verbs are even clearer.

(43) Dokne narasteš, 'grow up-2SG.PRS.PFV' bit ćeš malen.

'You will be small until you grow up.'

(44) $\quad$ ** Doknarasteš, 'grow up-2SG.PRS.PFV' nećeš biti malen.

**`Until you grow up, you will not be small.'

Nevertheless, the substandard present forms imadnem 'have-1sG.PRS2' and mognem 'can-1SG.PRS2' - typical of the idioms of Bosnia and Herzegovina and likely to be considered perfective only because they never express actual present nor they complement phasal verbs 20 - fit into sentences of this type the same way present budem does.

(45) (...) raditiću dokimadnem 'have-1SG.PRS2' snage za to.

'(...) I am going to work as long as there is strength in me.' (www.fojnica.ba)

(46) (...) igrat ću sve dok mognem 'can-1SG.PRS2'.

'I am going to play as long as I can.' (1900bayernmunchen.blogger.ba)

20 Although it might be assumed that these presents do not occur with phasal verbs because of their stative nature. 


\begin{tabular}{|l|l|}
\hline (47) & $\begin{array}{l}\text { (...) te price oko kradje i slicnog necu poticati dokne imadnem 'have-1SG.PRS2' } \\
\text { dokaze. }\end{array}$ \\
\hline & $\begin{array}{l}\text { '(..) I will not encourage these stories about the theft and the similar until } \\
\text { I have proof.' (forum.sportsport.ba) }\end{array}$ \\
\hline
\end{tabular}

\begin{tabular}{|l|l|}
\hline$(48)$ & (...) mogu listajati kod nekog dokne mognem 'can-1SG.PRS2' preuzeti? \\
\hline & $\begin{array}{l}\text { '...) can [the bottles] stay at someone's place till I am able to take them } \\
\text { over?' (volimpivo.ba) }\end{array}$ \\
\hline
\end{tabular}

It seems however that clauses containing the negated present forms imadnem and mognem, as well as clauses with typical perfective verbs, only denote boundary temporality (the emergence of one situation stipulates the end of another: dok= until), while clauses with ne budem can denote simultaneity (two parallel situations: dok $=$ while) as clauses with imperfective verbs do, but also boundary temporality, as clauses with perfective verbs do too, cf.

\begin{tabular}{|l|l|}
\hline (49a) & priče neću poticati sve dokne imadnem 'have-1SG.PRS2' dokaze. \\
\hline & 'I am not going to encourage the stories until I have proof.' \\
\hline
\end{tabular}

and

(49b) ${ }^{* *}$ Za vrijeme dokne imadnem 'have-1SG.PRS2' dokaze, neću poticati priče. 'As long as I have no proof, I will not encourage the stories.'

\begin{tabular}{|l|l|}
\hline (50a) & Ja ću paziti na djecu za vrijeme dok ti ne budeš 'be-2SG.PRS2' kod kuće. \\
\hline & 'I will look after the children while you are not at home.' \\
\hline (50b) & Ja ću paziti na djecu sve dokti ne budeš 'be-2SG.PRS2' kod kuće. \\
\hline & 'I will look after the children as long as you are not at home.' \\
\hline
\end{tabular}

To conclude this section, the imperfectiveness of budem is more firmly proven than the perfectiveness. It is relatively undoubtedly proved by its usage with phasal verbs, with expressions denoting development of a situation (for non-repeating situation), with the indicators of an included time and in dok clauses in cases where the usage of budem overlaps with the usage of imperfective verbs exclusively.

\subsection{Budem as a bi-aspectual verb form}

Although contexts that relatively unambiguously point to the perfectiveness or to the imperfectiveness of the present budem are relatively scarce, we believe that the given contexts can provide enough evidence to prove that the present budem cannot be considered either only perfective or only imperfective. In accordance with that, the terms perfective and imperfective present are obviously not adequate 
for the presents of the verb biti and they should not be used in grammatical description. Theoretically, they could be labelled imperfective and bi-aspectual present respectively, but as the bi-aspectuality of the present budem is rather specific or even problematic, and because the essence of the opposition between the two presents is not in aspect, the presents of the verb biti should rather be named after their formal characteristics, which cannot be questioned: athematic ( (je)sam $)$ and thematic (budem).

Given that the opposition between the thematic and the athematic present is not purely aspectual, Ivić poses the question at the end of his article on what is the true difference between the two presents. He concluded that jesam, which we prefer to call the athematic present, is the form used to denote the true present and the omnitemporality which encompasses the true present, as well as related usages in declarative clauses governed by verbs of saying and thinking (verba loquendi and verba existimandi) which can be reduced into these two categories, for example Mislila je da je najlepša. 'She thought she was the most beautiful', Reći ce da nije tako. '(S)he will say it is not so.' On the other hand, the present budem, which we call the thematic present, is, by Ivić's definition, a bi-aspectual present which is used as a perfective present and besides that it is used as an imperfective present in the cases that are not covered by the usage of jesam. In other words, according to Ivić, the two presents are complementary. In reality, the situation is more complex and the relationship between jesam and budem is not completely complementary. Actually, there are two basic cases in which the thematic and athematic presents do not concur - the actual present and the non-repeating omnitemporality are only denoted by the athematic present, while contexts or meanings in which future II is used are reserved for the thematic present exclusively. The future II tense will normally be used in some types of conditional, concessive and relative clauses in the broadest sense (including temporal, spatial, quantitative, qualitative etc. types of clauses) as well as in sentences of the type Možda ne bude struje. 'There might be no electricity', Možda tion bude nešto rekao. 'He might tell you something'. ${ }^{21}$

\section{Concurrence of the two presents}

There are, likewise, two basic cases in which thematic and athematic presents concur. The first is the case of repeated situations, as in

\begin{tabular}{|l|l|}
\hline (51) & $\begin{array}{l}\text { Često budem 'be-1SG.PRS2'/ sam 'be-1SG.PRS1' ljut, ali me uglavnom brzo } \\
\text { prođe 'go away-3SG.PRS.PFV' / prolazi 'go away-3SG.PRS.IPFV'. }\end{array}$ \\
\hline & 'I am often angry, but it usually goes away quickly.' \\
\hline
\end{tabular}

The thematic present here possibly functions as a perfective verb, and the athematic as an imperfective verb, but that cannot be easily proved. Generally speak-

21 For future II in dependent clauses with možda see Kovačević (2009). 
ing, this sort of concurrence between perfective and imperfective verbs should be explored in greater detail.

The next case, that of the volitive type sentences, is even more interesting. The core of this type of sentences consists of independent volitive sentences and dependent volitive clauses, by which we have named this type, while its periphery is constituted of a number of dependent clauses introduced with the conjunctions $d a$ and neka. Certain subject and object clauses belong to this type, as well as certain adverb clauses too, such as for example clauses of purpose. ${ }^{22}$ The shared characteristic of all dependent clauses of the volitive type is the possibility of hosting budem, but only budem that is not 'transferred' from independent declarative sentences transformed into dependent clauses and that does not denote future II). ${ }^{23} \mathrm{As}$ an alternative term for all volitive type dependent clauses in the sense of utterances without truth value the term quasi-subjunctive clauses might be used. ${ }^{24}$ In the independent and dependent volitive type sentences, the thematic present often corresponds to the athematic present in declarative sentences. In fact, it corresponds to them so often that Ivic thought the athematic present cannot be used in this type of sentences at all. However, in many, but not all, ${ }^{25}$ volitive type sentences, both the thematic present and the athematic present of the verb biti are used, especially in the everyday speech. The two presents concur when the situation of a volitive sentence includes future/posteriority (future in independent sentences and posteriority in dependent clauses) or is completely future/posterior. First of all, the volitive type sentences can denote past/anteriority, present/simultaneity, and future too.

In (52) and (53) past/anteriority is denoted.

\begin{tabular}{|l|l|}
\hline (52) & Neka sibio 'be-2SG.PRF' kod njih: to tije pametno. \\
\hline & 'You did well going to them: wisely done.' \\
\hline
\end{tabular}

\begin{tabular}{|l|l|}
\hline (53) & $\begin{array}{l}\text { Zahtijevalo se da su u trogodišnjem razdoblju bila 'be-3PL.PRF' financijski } \\
\text { stabilna (...) }\end{array}$ \\
\hline & $\begin{array}{l}\text { 'It was required of them [i.e. the companies] to have been financially stable } \\
\text { during the three previous years.' (business.hr) }\end{array}$ \\
\hline
\end{tabular}

In (54) and (55) present/simultaneity that does not include future/posteriority is expressed.

22 For the inclusion of a part of subject and object clauses, and clauses expressing intention into one (volitive) type clause, see Renzi, Salvi and Cardinaletti (1991: 416 f.).

23 Here we deal with numerous types of dependent clauses, some of which are far away from typical volitive clauses or do not express volition at all (for example, clauses dependent on phasal verbs). For the list containing the majority of them see Milošević (1971: 190-194). Complement volitive clauses are considered declarative in the (Serbo-)Croatian grammatical tradition (cf. Katičić 1991: 304 f. and Stevanović 1989: 832), which they are not as they lack the truth value. This type of clauses is not considered declarative in Kordić (1997: 55 f.) and neither, it seems, in Brown and Alt (2004: 73 f.).

24 Wayles Browne, personal communication.

25 Already mentioned exceptions are the dependent clauses regulated by verbs of fear and phasal verbs. 
(54) (...) primjetnaje 'be-3SG.PRS1' već neko vrijeme posve nova oglasna ploča. (...) 'For quite some time now it has been evident there is a new noticeboard.'

Ineka je 'be-3SG.PRS1', jer takoi treba.

'So be it, it's the way it should be.' (komin.com.hr)

(55) (...) htio bih da sam 'be-1SG.PRS1' u krivu, jer bi mi to umirilo maštu. 'I wish I were wrong because that would appease my imagination.' (blog.hr)

When non-repeating or repeated situations extend through a longer period of time and show certain features of omnitemporality, the borders between present/ simultaneity and future/posteriority are wiped out. In such cases, relatively often, both thematic and athematic presents are used (56)-(61)

(56) Želim da joju životu bude 'be-3SG.PRS2' dobro, nekaje 'be-3SG.PRS1' sretna. 'I wish her a good life, may she be happy.' (blog.hr)

(57) Neka ono prvo u našim molitvama bude 'be-3SG.PRS2': doprijeti do Isusa. 'Let the first thing in our prayers be: getting through to Jesus.'

Isus nekaje 'be-3SG.PRS1' prvi cilj svake molitve,(...)

'Let Jesus be the first goal of every prayer (...)' (zupa-kraljicekrunice.hr)

(58) (...) meni se ovako dugi rallyi sviđajui htio bih daje 'be-3SG.PRS1' ovakva svaka utrka.

'I like rallies this long and I would like every race to be like this.' (autosport.hr)

(59) (...) nastojiš da su 'be-3PL.PRS1' što rjeđi

'(...) you try to make them as rare as possible.' (forum.hr)

(60) Dijete kojeje odraslo snesavršenim roditeljem sretnije je od djece čiji su roditelji, nastojeći da budu 'be-3PL.PRS2' "savršeni”, pokazivali (...)

"The child that had grown up with an imperfect parent is happier than those children whose parents, while striving to be "perfect", were displaying (...)' (planetzoe.hr)

(61) Turisti žele da njihove potrebe budu 'be-3PL.PRS2' u prvom planu (...) 'Tourists wish their needs be of utmost importance.' (virturizam.hr) 
The athematic present has probably spread from similar examples to the contexts where the predication is undoubtedly future or posterior, and for that reason the athematic present concurs with the thematic present even in examples such as (62)-(66):

\begin{tabular}{|l|l|}
\hline (62) & $\begin{array}{l}\text { (...) dao Bog da se više ne ponovio, sad neka su 'be-3PL.PRS1' ubuduće bar nekih } \\
\text { 100 godina samo male obične ciklične recesije (...) }\end{array}$ \\
\hline & $\begin{array}{l}\text { 'God grant it repeats not again, let there be in the future, at least for some hun- } \\
\text { dred years, nothing else but common small cyclic recessions.' (eclectica.hr) }\end{array}$ \\
\hline
\end{tabular}

\begin{tabular}{|l|l|}
\hline (63) & $\begin{array}{l}\text { (...):neka vam budu 'be-3PL.PRS2' za hranu ... A zvijerima ... - nekaje 'be } \\
\text {-3SG.PRS1' za hranu sve zeleno (...) }\end{array}$ \\
\hline & $\begin{array}{l}\text { '...) This will be food for you.... for all the wildlife ... - I have given every } \\
\text { green plant for food. (...)' (katolici.org) }\end{array}$ \\
\hline
\end{tabular}

\begin{tabular}{|l|l|}
\hline$(64)$ & (...) htio bih daje 'be-3SG.PRS1' krajtužan \\
\hline & 'I would like the end to be sad.' (blog.hr) \\
\hline
\end{tabular}

\begin{tabular}{|l|l|}
\hline$(65)$ & $\begin{array}{l}\text { (...) sviđaš mi se i htio bih da budemo 'be-1PL.PRS2' više od prijatelja ili nešto } \\
\text { slično.. }\end{array}$ \\
\hline & $\begin{array}{l}\text { 'Ilike you and I would like us to be more than friends or something like } \\
\text { that.' (mojforum.hr) }\end{array}$ \\
\hline
\end{tabular}

\begin{tabular}{|l|l|}
\hline (66) & $\begin{array}{l}\text { (...) drago mi je kaj Vam se dopadaju moji tekstovi pa ću nastojat da budu 'be } \\
\text {-3PL.PRS2' još bolji. }\end{array}$ \\
\hline & $\begin{array}{l}\text { '(..) I am glad you like my texts, so I will try to make them even better.' } \\
\text { (vecernji.hr) }\end{array}$ \\
\hline
\end{tabular}

The interrelationship between the thematic and the athematic present in this type of sentences should be investigated in greater detail. But preliminarily, it can be assumed that the choice between them depends on, according to the probability of relevance: region, the tense in the main clause (in certain examples), the type of predicate (a full verb or a copula), style (the conversational style seems to make use of the athematic present more often than higher registers), etc. The assumptions about regional variants are surely justified - for example, in the Central Čakavian dialect of Kukljica on the island of Ugljan, as evidenced by our own corpora, in volitive type sentences, the athematic present is far more common than the thematic present. ${ }^{26}$ In the Osijek dialect the thematic present in volitive type sentences

26 For more details about the interrelation between the athematic and thematic presents of the verb biti in Kukljica dialect see Benić (to appear): $§ 61$. 
seems to be quite more common than in Kukljica. This could point to the possibility of regional variation between certain littoral and continental (at least East Slavonia) idioms.

Finally, it should be noted that the distribution of the two present paradigms, when functioning as auxiliary verbs in the passive voice formed with the participle (budem prebačen 'I am transferred'), matches, in the majority of cases, the distribution of the athematic and thematic presents as both full and copulative verbs (budem u kuhinji 'I am in the kitchen' and budem dobar 'I am good' respectively')27. Thus, along with budem + the past passive participle in constructions with neka (cf. neka bude prebačen 'let him be transferred'), which can be considered imperative, and the passive present of the type on je prebačen 'he is transferred', there is also a passive present bude prebačen 'is transferred', which is homonymous in Croatian to the passive future II bude prebačen 'will be transferred'. This type of passive present denotes non-repeating past situations (historical present) and repeated present situations in independent and dependent clauses of various types, and occurs as a relative tense in dependent clauses in volitive type sentences.

The next four examples contain a budem + past passive participle construction, but only in (67) it can be understood as the future II, while in (68)-(70) it can be understood exclusively as the present tense. This is confirmed by the substitution test, that is by the replacement of the participial passive with the active or the reflexive passive construction, in the case of which the present and the future II do not overlap.

\begin{tabular}{|l|l|}
\hline (67) & $\begin{array}{l}\text { Ukoliko ne želite slati potvrdu, pričekajte nekoliko dana dok Vaša uplata ne } \\
\text { bude 'be-3SG.PRS2' proknjižena. }\end{array}$ \\
\hline & $\begin{array}{l}\text { 'If you do not want to send the confirmation, wait a few days for your } \\
\text { payment to be processed.' (zvu.hr) }\end{array}$ \\
\hline
\end{tabular}

The form dok ne bude proknjižena can be replaced with both dok se ne proknjiži 'process-3SG.PRS-PFV-REFL' and dok se ne bude proknjižila 'process-3SG.FUT IIPFV-REFL' (all three translatable as 'before it is processed').

\begin{tabular}{|l|l|}
\hline (68) & $\begin{array}{l}\text { O Mitrovu-dne on se iseli odavde ... a pre mesec dana bude 'be-3SG.PRS2' } \\
\text { premešten u Valjevo. }\end{array}$ \\
\hline $\begin{array}{l}\text { 'On Mitrov-day he moved away from here, and a month ago he was tran- } \\
\text { sferred to Valjevo.' (Milošević 1971: 190) }\end{array}$ \\
\hline
\end{tabular}

Bude premešten can be replaced with premeste 'transfer-3PL.PRS-PFV' ga 'they transfer him', but not with budu ga premestili 'transfer-3PL.FUTII-PFV' 'they have transfered him'.

27 This is, of course, not the case in the verb forms formed by combining the verb to be and the active past participle. 
(69) Utrenutku kad to bude 'be-3SG.PRS2', koplje vezano za ruku lovca zarije se u životinju, koja za čas bude 'be-3SG.PRS2' izvučena iz vode i ubijena.

'In the moment when this happens, the spear tied to the hunter's hand is stuck into the animal, which is soon pulled out of water and killed.' (Milošević 1971: 190)

Bude izvučena iz vode i ubijena can be replaced with koju izvuku 'pull out-3PL. PRS-PFV' iz vode i ubiju 'kill-3PL.PRS-PFV' 'that they pull out of water and kill', but not with koju budu izvukli 'pull out-3.PL.FUTII-PFV' iz vode i ubili 'kill-3PL.FUTII-PFV' 'that they have pulled out of water and killed'.

\begin{tabular}{|l|l|}
\hline (70) & $\begin{array}{l}\text { Haulikje od Kässmanna tražio da skulpture budu 'be-3SG.PRS2' izrađene u } \\
\text { potpuno prirodnim veličinama. }\end{array}$ \\
\hline & $\begin{array}{l}\text { 'Haulik demanded that Kässmann should make the sculptures completely } \\
\text { life-size.' (park-maksimir.hr) }\end{array}$ \\
\hline
\end{tabular}

Budu izradene can be substituted with da se izrade 'make-3PL.PRS-PFV-REFL', but not with da se budu izradile 'make-3PL.FUTII-PFV-REFL'.

Paradoxically, budem + past passive participle formations (i.e. forms such as budem prebačen) are described (almost) exclusively as the future II in BCMS grammars, which is inaccurate for at least two reasons. First of all, almost all cases of the passive which are formed with the past participle belong to perfective verbs, so it appears more logical to consider all usages we have mentioned thus far as present forms. Even in (67) the syntagm uplata ne bude proknjižena 'the payment is not processed' could be understood as a perfective present form functioning as a future II form. The only cases that have to be understood as future II forms are the imperfective forms such as budem prebacivan 'I will be transferred'. Secondly, and far more important, almost fifty years ago, the present usage of the type budem prebačen was described in detail by Ksenija Milošević (Milošević 1971). Despite that, the same as the aforementioned Ivićs article, her work never received the attention it deserves. The only Croatian linguist who noticed that budem is used in forming both passive present and passive future II is Stjepan Babić (Babić et al. 1991: 719). ${ }^{28}$

\section{Conclusion}

Ever since Daničićs time, the difference between the two presents of the verb biti 'to be' has been reduced to aspectual opposition in grammars, with two exceptions (Babić et al. 1997 and Browne 1993: 338; Brown and Alt 2004: 54). On the other hand, this problem was dealt with in the more theoretically-oriented linguis-

28 Although the interpretation of the combination budem + passive participle as present passive or as future II does not depend on whether this combination marks state or a process, as can be assumed from Babićs text. 
tic works, as Ivić did 65 years ago. He managed to describe their interrelationship relatively well, holding that the present budem should be considered a bi-aspectual verb and jesam an imperfective verb. At the same time, he considered the presents jesam and budem as two chiefly complementary forms - jesam as imperfective and budem as perfective, with the addition that the latter is used imperfectively in the cases or contexts where jesam is not used. Ivić was mostly right, but his evidence was never strong enough. In this light, our main intention was to clarify the question of aspect. In that respect, we have determined contexts that more or less undoubtedly prove, respectively, the perfectiveness or imperfectiveness of the present bu$\mathrm{dem}$. The perfectiveness is relatively undoubtedly proved in da clauses depending on pričekati 'to wait (until X occurs)' and in clauses regulated by verbs of fear, while the fact that budem cannot denote true present only points to the possibility of perfectiveness. On the other hand, budem is relatively undoubtedly imperfective when used with phasal verbs, with expressions denoting the development of a situation (for non-repeating situations), in cases in which it encompasses the time interval of the main clause, and in dok clauses in contexts where it overlaps with the usage of imperfective verbs.

Given that the difference between the two presents in question is only partially aspectual, we propose terms according to their forms, whose accuracy cannot be doubted, terms that also happen to be rather brief: athematic present and thematic present. Concerning the interrelationship between the two presents, we hold that they are not as complementary as Ivić believed them to be. Moreover, they display a high degree of concurrence in two cases: in sentences with iterative present and in volitive type sentences. This concurrence, especially in the latter case, is an interesting phenomenon that requires further examination. At this moment, we can declare as sure that the interrelationship between the two presents in volitive type sentences differs depending on the region in Croatia. The distribution of the athematic and thematic presents is similar, no matter whether the present features as the main or auxiliary verb in the formation of the passive voice, as shown in Milošević (1971), where the present usage of budem + passive participle (budem prebačen etc.) is described. Unfortunately, usage of that type is usually not recorded in grammatical descriptions.

Dealing with the presents of the verb biti 'to be', we have discovered certain less known features that we were not aware of earlier. Despite that, it is impressive to see how much time it can take for a fundamental fact to make its way from a scholarly work to a grammar book. This fact is all the more amazing since the given considerations come from two linguists who were distinguished in the area of former Yugoslavia. If Ivićs argumentation can be considered as insufficiently precise, the topic of Ksenija Milošević's article is concrete enough to prevent taking her argumentation as imprecise. Nevertheless, the fact is that the 48 years in question have not been enough time, with the exception of S. Babić (Babić et al. 1991), for the present passive such as budem prebačen to be fully acknowledged in grammars. 
We hope that this will change soon enough, that is, that we will not have to wait for another fifty years for the majority of grammars to revise their considerations about both the aspect of the form budem and the temporal meaning of forms such as budem prebačen.

\section{Bibliography}

Ronelle, Alexander (2006). Bosnian, Croatian, Serbian, a Grammar. With Sociolinguistic Commentary. Madison, WI: University of Wisconsin Press

Stjepan Babić et al. (1991). Povijesni pregled, glasovi i oblici hrvatskoga književnog jezika, Nacrt za gramatiku, Zagreb: Hrvatska akademija znanosti i umjetnosti, Nakladni zavod Globus

Barić, Eugenija et al. (1997). Hrvatska gramatika. Zagreb: Školska knjiga

Benić, Mislav (2014). Opis govora Kukliice. Doctoral thesis. Zagreb: University of Zagreb

Benić, Mislav (to appear). Gramatika govora Kukljice. Zagreb: Institut za hrvatski jezik i jezikoslovlje

Bičanić, Ante, Anđela Frančić, Lana Hudeček, and Milica Mihaljević (2013) Pregled povijesti, gramatike i pravopisa hrvatskogajezika. Zagreb: Društvo za promicanje hrvatske kulture i znanosti Croatica

Brabec, Ivan, Mate Hraste, and Sreten Živković (1968). Gramatika hrvatskosrpskoga jezika. Zagreb: Školska knjiga

Brown 29, Wayles, and Theresa Alt (2004). A Handbook of Bosnian, Serbian, and Croatian. Slavic and East European Language Research Center, Duke University, http://www.seelrc.org:8080/grammar/mainffame.jsp?nLanguageID=l

Browne, Wayles (1993). Serbo-Croat. Comrie, Bernard, and Greville G. Corbett, eds. The Slavonic Languages. London - New York: Routledge, 306-387

Broz, Ivan, and Franjo Iveković (1901). Rječnik hrvatskog jezika, vol I. Zagreb: Štamparija Karla Albrechta (Jos. Wittasek)

Budmani, Pietro (1867). Grammatica della lingua serbo-croata (illirica). Vienna: A Spese dell'Autore

Comrie, Bernard (1976). Aspect. An Introduction to the Study of Verbal Aspect and Related Problems. Cambridge - London - New York - Melbourne: Cambridge University Press

Čirgić, Adnan, Pranjković, Ivo, and Josip Silić (2010). Gramatika crnogorskoga jezika. Podgorica: Pobjeda AD

Dahl, Östen (1985). Tense and Aspect Systems. Oxford - New York: Basil Blackwell

Daničić, Đuro (1863). Oblici srpskoga jezika, Beograd: Državna štamparija

Daničić, Đuro (1880-1882). Rječnik hrvatskoga ili srpskoga jezika, vol 1. Zagreb: Jugoslavenska akademija znanosti i umjetnosti

Dickey, Stephen (2000). Parameters of Slavic aspect. A cognitive approach. Stanford: Center for the study of language and information

29 The surname Browne is misspelled in the publication as Brown. 
Grickat, Irena (1958). O nekim vidskim osobenostima srpskohrvatskog glagola. Južnoslovenski filolog XXII: 65-130

Grubor, Đuro (1953). Aspektna značenja, Rad JAZU 293, 4. Zagreb: Jugoslavenska akademija znanosti i umjetnosti

Gudkov, Vladimir Pavlovič (1969). Serboxorvatskij jazyk: grammatičeskij očerk, literaturnye teksty s kommentarijami i slovarëm. Moskva: Izdatel'stvo Moskovskogo universiteta

Hammond, Lila (2005). Serbian: An Essential Grammar. London - New York: Routledge Taylor and Francis Group

Ivić, Pavle (1955). O vidu glagolskog oblika budem. Naš jezik, VI, vols. 7-10: 237-245

Ivić, Milka (1958). Slovenski imperativ uz negaciju. Radovi naučnog društva NR Bosne i Hercegovine 10/4: 23-44

Jahić, Dževad, Senahid Halilović, and Ismail Palić (2004). Gramatika bosanskoga jezika za srednje škole. Zenica: Dom štampe

Kalsbeek, Janneke (1998). The Čakavian dialect of Orbanići near Žminj in Istria. Amsterdam - Atlanta: GA

Katičić, Radoslav (1991). Sintaksahrvatskogaknjiževnogjezika:nacrtzagramatiku. Zagreb:HAZU

Klajn, Ivan (2005). Gramatika srpskogjezika. Beograd: Zavod za udžbenike i nastavna sredstva Kordić, Snježana (1997). Serbo-Croatian. München: Lincom Europa

Kovačević, Miloš (2009). Upotreba futura II u prostoj rečenici. Srpski jezik14/1-2: 65-76

Leskien, August (1914). Grammatik der serbo-kroatischen Sprache. Heidelberg: Carl Winter - Universitätsverlag

Maretić, Tomo (1931). Gramatika i stilistika hrvatskoga ili srpskoga književnog jezika. Zagreb: Obnova

Maslov, Jurij Sergeevič (2004). Izbrannye trudy. Aspektologija. Obščee jazykoznanie. Moskva: Jazyki slavjanskoj kul'tury

Meillet, Antoine, and André Vaillant (1924). Grammaire de la langue serbo-croate. Paris: Champion

Milošević, Ksenija (1971). Jedan slučaj asimetrije između izraza i sadržine u gramatičkom sistemu savremenog srpskohrvatskog jezika. Vremensko značenje konstrukcije budem + particip pasivni. Radovi ANUBIH 41: 181-203

Padučeva, Elena Viktorovna (2010). Semantičeskie issledovanija. Semantika vremeni i vida v russkom jazyke. Semantika narrative. Moskva: Jazyki slavjanskoj kul'tury

Padučeva, Elena Viktorovna (2015). O biaspektual'nosti russkogo glagola byt'. Kitadzë, and Micusi, eds. Aspektual'naja semantičeskaja zona: tipologija sistem i scenarii diahroničeskogo razvitija. Sbornik statej v Meždunarodnoj konferencii Komissii po aspektologii Meždunarodnogo komiteta slavistov, Kioto: Universitet Kioto Sangë, 176-184

Renzi, Lorenzo, Giampaolo Salvi, and Anna Cardinaletti (eds.) (1991). Grande grammatica italiana di consultazione. Vol. II. I sintagmi verbale, aggettivale, avverbiale; la subordinazione. Bologna: Il Mulino

Riđanović, Midhat (2012). Bosnian for Foreigners with a Comprehensive Grammar. Sarajevo: RABIC Publishing Company 
Silić, Josip, and Ivo Pranjković (2005). Gramatika hrvatskoga jezika - za gimnazije i visoka učilišta. Zagreb: Školska knjiga

Stevanović, Mihajlo (1989). Savremeni srpskohrvatski jezik (gramatički sistemi i književnojezička norma). II Sintaksa. Beograd: Naučna knjiga

Šimić, Ana, and Jozo Vela (2018). Dijakronijska analiza odnosa vida i pravoga jednostavnoga niječnog imperativa u hrvatskom jeziku. Fluminensia 30(2): 171-188, https://doi.org/10.31820/f.30.2.10

Veljković, Dragana (2015). Aspektualne vrednosti pomoćnih glagola biti i jesam u srpskom jeziku. Dimitrijević, Bojana, ed. Nauka i suvremeni univerzitet: Jezik i književnost u kontaktu i diskontaktu IV, vol. 1 Zbornik sa IV. naučnog skupa Nauka i savremeni univerzitet, Niš: Filozofski fakultet Univerziteta u Nišu, 17-29

Veselý, Luboš (2011). O vidu slovesa soustředit se. Příspěvek k otázce jazykové správnosti. Naše řeč 94(3): 134-141

Vuković, Jovan (1937). Pitanje glagolskog vida oblika budem. Zbornik lingvističkih i filoloških rasprava A. Beliću o četrdesetogodišnjici njegova naučnog rada posvećuju njegovi prijatelji i učenici. Beograd: Mlada Srbija, 231-232

Vuković, Jovan (1957). Posebna vidska vrednost aorista kod ponekih glagola stanja u srpskohrvatskom jeziku. Slavistična revija, Časopis za literarno zgodovino in jezik. Rajku Nahtigalu za osamdesetletnico. X. Letnik, 1-4. Ljubljana: 237-252

Zaliznjak, Anna Andreevna, and Aleksej Dmitrievič Šmelëv (2000). Vvedenie v russkuju aspektologiju. Moskva: Jazyki russkoj kul'tury

\section{O vidu dvaju prezenata glagola biti u hrvatskom}

Od Daničićeva vremena pa do suvremenih standardnih gramatika poput Barić i dr. (1997), Silić i Pranjković (2005) razlika se među dvama prezentima glagola biti u većini gramatika svodi na vidsku opreku (prezent jesam smatra se nesvršenim, a prezent budem svršenim), dok se u manjem broju gramatika ne govori o vidu dvaju prezenata. Jedine su iznimke gramatike Stjepana Babića i suradnika (1991: 688, 719) i Waylesa Brownea (Browne 1993: 338 i Brown i Alt 2004: 54), gdje se prezent jesam smatra nesvršenim, a prezent budem dvovidnim. Lingvistička je pak literatura vid prezenta budem propitivala u više navrata. Najznačajniji je u tom smislu rad Pavla Ivića (1955), koji je jesam i budem smatrao dvama komplementarnim oblicima stavljajući nesvršeni prezent jesam u opoziciju sa svršenim budem, ali uz dodatak da se potonji rabi nesvršeno u kontekstima u kojima ne dolazi jesam. Rezultati pretraživanja hrvatskih digitalnih korpusa i mrežnih stranica pokazuju da je Ivić bio na pravome tragu, premda nije pružio dovoljno dokaza kojima bi potkrijepio tvrdnje. U članku predstavljamo niz konteksta koji upućuju na dvovidnost prezenta budem. Njegovu svršenost relativno nedvojbeno dokazuju rečenice s veznikom da zavisne od glagola pričekati i rečenice zavisne od glagola bojazni, a indicijom se svršenosti u nekim kontekstima može smatrati i činjenica da prezent budem ne može označavati pravu sadašnjost. S druge strane, prezent je budem relativno nedvojbeno nesvršen u klauzama uz fazne glagole, uz izraze koji znače razvijanje procesa (za jednokratne procese), u slučajevima kad vremenski obuhvaća događaj u surečenici te u zavisnim rečenicama s dok u kontekstima u kojima se i zanijekan i nezanijekan preklapa s uporabom nesvršenih glagola.

U konačnici, kako je razlika među dvama prezentima glagola biti tek dijelom vidska, predlažemo nove nazive za njih: atematski prezent (jesam) i tematski prezent (budem). Ti su nazivi stvoreni na temelju formalnih osobina dvaju prezenata, pa ih nije lako osporiti. Međuodnos prezenata jesam i budem nije komplementaran kako smatra Ivić, već među njima postoji nezanemariv stupanj konkurencije u dva 
slučaja: u rečenicama s iterativnim prezentom i u rečenicama zahtjevnoga tipa. Međuodnos atematskoga i tematskoga prezenta sličan je bez obzira na to je li biti glavni glagol ili pomoćni glagol za tvorbu pasiva. Naime, još je Ksenija Milošević (1971) pokazala da prezent budem s pridjevom trpnim ima značenje i futura II. pasivnog i prezenta pasivnog. Ipak, prezent pasivni tvoren od budem i pridjeva trpnog do danas, uz iznimku gramatike Babića i suradnika (Babić et al. 1991), nije u dovoljnoj mjeri registriran u gramatikama.

Keywords: verb to be, verbal aspect, thematic present, athematic present, Croatian language Ključne riječi: glagol biti, glagolski vid, tematski prezent, atematski prezent, hrvatski jezik 